\title{
Characteristics and potential sources of wintertime air pollution in Linfen, China
}

\author{
Lei Liu $\cdot$ Xin Ma $\cdot$ Wei Wen $\cdot$ Chang Sun $\cdot$ \\ Jiao Jiao
}

Received: 1 December 2020 / Accepted: 28 March 2021 / Published online: 8 April 2021

(C) The Author(s), under exclusive licence to Springer Nature Switzerland AG 2021

\begin{abstract}
Linfen in China's Shanxi Province suffers severe air pollution in winter. Understanding the characteristics of air pollution and providing scientific support to mitigate such pollution are urgent matters. This study investigated the variations of $\mathrm{PM}_{2.5}, \mathrm{PM}_{10}, \mathrm{NO}_{2}, \mathrm{SO}_{2}, \mathrm{O}_{3}$, and $\mathrm{CO}$ in Linfen between December 1, 2019 and February 29, 2020. The mean concentrations of $\mathrm{PM}_{2.5}, \mathrm{PM}_{10}, \mathrm{NO}_{2}, \mathrm{SO}_{2}$, MDA8 (the maximum daily 8 -h average) $\mathrm{O}_{3}$, and
\end{abstract}

Supplementary Information The online version contains supplementary material available at https://doi. org/10.1007/s10661-021-09036-8.

\section{Liu}

State Key Laboratory of Severe Weather \& Key Laboratory of Atmospheric Chemistry of China Meteorological Administration, Institute of Atmospheric Composition and Environmental Meteorology, Chinese Academy of Meteorological Sciences, Beijing 100081, China

\section{Ma}

National Meteorological Center, Beijing 100081, China

W. Wen $(\bowtie)$

School of Energy and Environmental Engineering, University of Science and Technology Beijing, Beijing 100083, China

e-mail: brianwenwei@163.com

C. Sun

Beihang University, Beijing 100191, China

J. Jiao

Beijing Polytechnic, Beijing 100176, China
CO were 106.2, 139.4, 47.2, 41.0, 57.0 $\mu \mathrm{g} \mathrm{m}^{-3}$, and $1.8 \mathrm{mg} \mathrm{m}^{-3}$, respectively. Large amounts of pollutants emitted by coal burning, industry, vehicles, and residents contributed to air pollution. Unfavorable meteorological conditions, such as lower temperature, weaker wind, higher relative humidity, and reduced planetary boundary layer height, made the situation worse. Fireworks and firecrackers set off to celebrate traditional Chinese festivals caused the concentration of PM pollutants to spike, with the maximum daily mean concentration of $\mathrm{PM}_{2.5}$ reached $314 \mu \mathrm{g} \mathrm{m}^{-3}$ and the peak hourly value reached $378.0 \mu \mathrm{g} \mathrm{m}^{-3}$. Suspensions of commercial and social activities due to COVID-19 reduced anthropogenic emissions, mainly from industry and transportation, which decreased the level of air pollutants other than $\mathrm{O}_{3}$. Analyses involving backward trajectory cluster, the potential source contribution function, and concentration weighted trajectory demonstrated that $\mathrm{PM}_{2.5}$ pollution mainly came from local emissions in Shanxi Province and regional transport from Inner Mongolia, Shaanxi, Hebei, Henan, and Gansu provinces. Shanxi and its surrounding provinces should adopt measures such as tightening environmental management standards, promoting the use of renewable energy, and adjusting the transportation structure to reduce regional emissions. This study will help policy-makers draft plans and policies to reduce air pollution in Linfen.

Keywords Air pollution $\cdot \mathrm{PM}_{2.5} \cdot$ Meteorological parameters $\cdot$ Potential source $\cdot$ Linfen 


\section{Introduction}

Over the past few decades, due to China's accelerated industrialization and urbanization, the rapid increase in energy demand dominated by fossil fuels has worsened air quality. Air pollution endangers human health, increasing the mortality and morbidity of cardiovascular and respiratory diseases; impedes the sustainable development of society and the economy; and causes climate change (Mulenga \& Siziya, 2019; Shang, 2013; Shrivastava, 2017; Xie et al., 2019). As a severe environmental problem, air pollution has elicited concern among government officials and the public.

At the beginning of 2013, extreme and persistent air pollution appeared in China. Measurements in 74 major cities indicated that the daily mean concentrations of particulate matter (PM) with aerodynamic diameters smaller than $2.5 \mu \mathrm{m}\left(\mathrm{PM}_{2.5}\right)$ and $10 \mu \mathrm{m}\left(\mathrm{PM}_{10}\right)$, nitrogen dioxide $\left(\mathrm{NO}_{2}\right)$, sulfur dioxide $\left(\mathrm{SO}_{2}\right)$, carbon monoxide $(\mathrm{CO})$, and the maximum daily 8 -h average (MDA8) concentrations of ozone $\left(\mathrm{O}_{3}\right)$ exceeded the thresholds stipulated by National Ambient Air Quality Standard of China (NAAQS; GB3095-2012, Grade II) in 68.9\%, $46.9 \%, 14.9 \%, 23.5 \%, 12.3 \%$, and $1.2 \%$ of days in January-with maximum values up to $766 \mu \mathrm{g} \mathrm{m}^{-3}$, $998 \mu \mathrm{g} \mathrm{m}^{-3}, 491 \mu \mathrm{g} \mathrm{m}^{-3}, 186 \mu \mathrm{g} \mathrm{m}^{-3}, 10.9 \mathrm{mg} \mathrm{m}^{-3}$, and $258 \mu \mathrm{g} \mathrm{m}^{-3}$, respectively (air quality report of 74 cities in China in January 2013. 2013). The State Council of China promulgated the Action Plan for Air Pollution Prevention and Control (Air pollution prevention and control action plan. 2013) to deal with air pollution and public health protection. A series of stringent policies and measures aimed at reducing pollution emissions and promoting energy conservation have since been implemented.

After 5 years of effort in implementing these policies, the overall air quality has improved dramatically. The $\mathrm{PM}_{2.5}$ mean concentrations in the BeijingTianjin-Hebei (BTH) region, the Pearl River Delta region, and the Yangtze River Delta (YRD) region decreased by $39.6 \%, 27.7 \%$, and $34.3 \%$ by 2017 relative to 2013 levels (Announcement on the final assessment results of the implementation of the Air Pollution Prevention and Control Action Plan. 2018). However, air pollution remains serious in North China, with haze events frequently occurring in autumn and winter, especially during the heating period (An, 2019; Liu et al., 2020; Wen et al., 2018, 2020). In June 2018, the policy titled "Three-year action plan for protecting the blue skies" (Threeyear action plan for defending the blue sky. 2018) was released. The policy focused on three key regions: the $\mathrm{BTH}$ and surrounding areas, the YRD, and the Fenwei Plain (FWP). The plan aims to significantly improve air quality through continued preventive and control measures to realize the sustainable development of the society, economy, and environment.

Because of the massive increase in energy for heating and adverse meteorological conditions, the mean concentrations of $\mathrm{PM}_{2.5}$ in the FWP during autumn and winter are approximately twice of those in spring and summer, and heavy pollution days accounted for more than $90 \%$ of the whole year of 2018 (Action plan for comprehensive treatment of air pollution in the Fenwei Plain in the autumn and winter of 2019-2020. 2019). Linfen is one of eleven cities in the FWP with major pollution problems. It is situated in the southwest of Shanxi Province (Fig. 1), with Taiyue Mountain and Luliang Mountain around it. The Fen River flows from north to south through the middle of the city, forming the Linfen Basin. Linfen has a semi-arid and semihumid temperate continental climate with a resident population of approximately 4.5 million. Its GDP has grown at an average annual rate of $7.8 \%$, reaching RMB144 billion in 2018 (A review of the economic and social development achievement of Linfen. 2019). Linfen possesses particularly abundant coal and iron ore resources, with total reserves of 96 billion tons and 420 million tons, respectively. It is an essential part of the energy and chemical industry base of Shanxi Province and is one of the three major high-quality coking coal bases in China. Linfen has a heavy industrial structure, with coal, coke, steel, and electricity as the leading industries, resulting in large quantities of industrial emissions. Numerous industrial factories are located within a few kilometers of the urban area of the city. Coal and coke are mainly transported by road, and vehicle exhaust emissions are a serious problem. Linfen has been suffering perennial severe air pollution (Ma et al., 2015), and in January 2019, it had the worst air quality among Chinese cities (Air quality report 


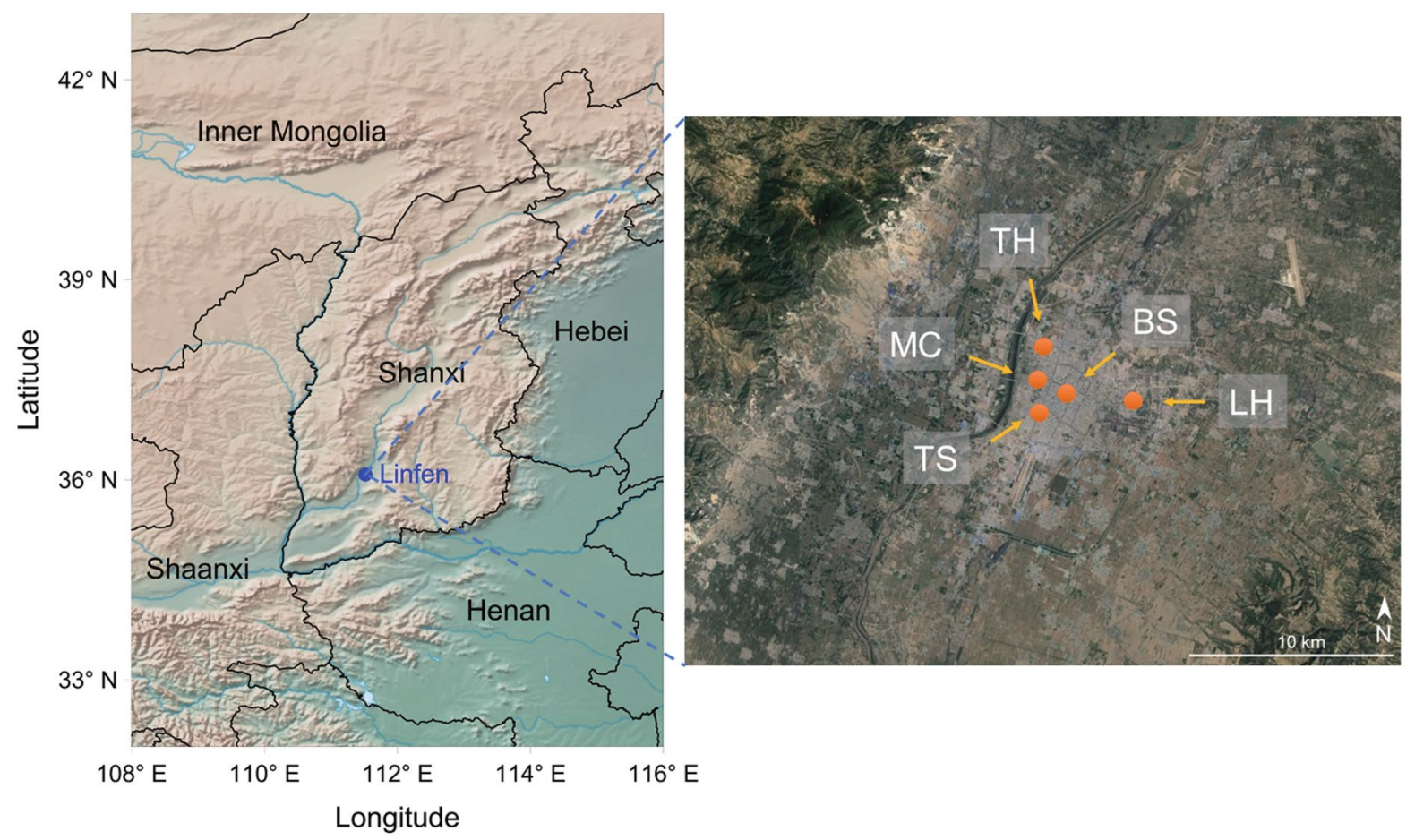

Fig. 1 Location of Linfen and the air quality monitoring stations (marked by orange dots). The Tangyao Hotel, Municipal Committee, Technical School, Business School, and Lingang Hospital sites are marked as TH, MC, TS, BS, and LH, respectively

in Chinese cities in January 2019. promulgated the Action Plan for Air Pollution Prevention and Controlpromulgated the Action Plan for Air Pollution Prevention and Control2019). Hence, raising awareness of air pollution in Linfen and providing scientific support to mitigate such pollution are urgent matters. However, detailed research related to air pollution in Linfen is still lacking.

This study comprehensively analyzed the characteristics of $\mathrm{PM}_{2.5}, \mathrm{PM}_{10}, \mathrm{NO}_{2}, \mathrm{SO}_{2}, \mathrm{CO}$, and $\mathrm{O}_{3}$ in Linfen during the winter of 2019 to 2020 - a period that covers the Spring Festival and the outbreak of the COVID-19 in China. The Spring Festival is the most important traditional festival in China. Families get together to celebrate the Lunar New Year's arrival by setting off firecrackers, which may cause severe environmental pollution. Because of the importance of meteorological parameters to air quality, their effects on air pollutant concentrations were discussed. The transport pathways and potential source areas of air pollutants were identified using the backward trajectory cluster, the potential source contribution function (PSCF), and concentration weighted trajectory (CWT). The results will help policy-makers draft plans and policies to reduce air pollution in Linfen.

\section{Methods}

Site location and monitoring data

Five national air quality monitoring stations located in Linfen, Shanxi Province, were selected for this study. Figure 1 shows the geographic location of Linfen and the monitoring stations. The stations are situated in the center of Linfen Basin and the urban area of Linfen, including Tangyao Hotel $\left(\mathrm{TH} ; 36.10^{\circ} \mathrm{N}, 111.51^{\circ} \mathrm{E}\right)$, Municipal Committee (MC; $\left.36.09^{\circ} \mathrm{N}, 111.50^{\circ} \mathrm{E}\right)$, Technical School (TS; $\left.36.07^{\circ} \mathrm{N}, 111.50^{\circ} \mathrm{E}\right)$, Business School (BS; $36.08^{\circ} \mathrm{N}, 111.52^{\circ} \mathrm{E}$ ), and Lingang Hospital (LH; $\left.36.08^{\circ} \mathrm{N}, 111.55^{\circ} \mathrm{E}\right)$. The automatic continuous monitoring systems of ambient air quality were used to monitor the concentrations of $\mathrm{PM}_{2.5}, \mathrm{PM}_{10}, \mathrm{NO}_{2}, \mathrm{SO}_{2}, \mathrm{CO}$, and 
$\mathrm{O}_{3}$ according to China's environmental protection standards (HJ817-2018 and HJ 818-2018). The hourly concentrations of $\mathrm{PM}_{2.5}, \mathrm{PM}_{10}, \mathrm{NO}_{2}, \mathrm{SO}_{2}, \mathrm{CO}$, and $\mathrm{O}_{3}$ were collected from China's Urban Air Quality Real-time Publishing Platform (http://106.37.208.233:20035) for the period of December 1, 2019 to February 29, 2020, which coincided with the central heating period in winter. The citywide mean concentrations of pollutants were obtained by averaging the concentrations of all stations. The daily mean concentrations were obtained from the data recorded for more than $20 \mathrm{~h}$ per day. The 8-h $\mathrm{O}_{3}$ concentrations were obtained for an 8-h block when data for $>6 \mathrm{~h}$ of that block were valid. The monthly averages were obtained by averaging the daily values of the month.

Hourly meteorological data of Linfen station $\left(36.07^{\circ} \mathrm{N}, 111.50^{\circ} \mathrm{E}\right)$, including temperature, wind speed, wind direction, relative humidity, and visibility, were provided by China National Meteorological Science Data Center (http://data.cma.cn). The planetary boundary layer height (PBLH) was obtained from ERA5 provided by the European Center of Medium-Range Weather Forecasts (https://www.ecmwf.int/).

\section{Backward trajectory cluster analysis}

Seventy-two-hour backward trajectories arriving at the center of Linfen $\left(36.08^{\circ} \mathrm{N}, 111.52^{\circ} \mathrm{E}\right)$ were computed by the Hybrid Single-Particle Lagrangian Integrated Trajectory model. The meteorological data with a resolution of $1^{\circ} \times 1^{\circ}$ was obtained from the Global Data Assimilation System of the US National Centers for Environmental Prediction (ftp://arlftp. arlhq.noaa.gov/pub/archives/gdas1). The model was run four times a day at the starting times of 0:00, 6:00, 12:00, and 18:00 local time at the height of $100 \mathrm{~m}$ above ground level during the study period. Cluster analysis was applied for group trajectories, and the main transport pathways associated with elevated pollutant concentrations were identified by the combination of trajectories and pollutant concentrations.

\section{Source region analysis}

The potential source areas of $\mathrm{PM}_{2.5}$ were determined using the PSCF and CWT methods. Specifically, the estimates of the motion of trajectories were combined with pollutant concentrations of the receptor site using TrajStat, a geographic information system-based software (Wang et al., 2009). The study domain with a $1^{\circ} \times 1^{\circ}$ latitude and longitude was divided into small grid cells $(i \times j)$ with equal size. The PSCF value for cell $i j$ was computed as follows:

$P S C F_{i j}=\frac{m_{i j}}{n_{i j}}$

where $n_{i j}$ represents the number of endpoints falling into the cell $i j$, and $m_{i j}$ represents the number of endpoints corresponding to pollutant concentration higher than the pollution criterion in the same cell when reaching the receptor site. The pollution criterion of $\mathrm{PM}_{2.5}$ concentration was set to $75 \mu \mathrm{g} \mathrm{m}^{-3}$.

PSCF cannot tell the difference of grid cells with the same computed values when the pollutant concentrations slightly or significantly exceeded the criterion. The CWT method was used to overcome this limitation of PSCF. In the CWT model, a weighted concentration was assigned to each grid cell by averaging the pollutant concentrations of trajectories related to the grid cell, as shown below:

$C_{i j}=\frac{\sum_{l=1}^{M} C_{l} \tau_{i j l}}{\sum_{l=1}^{M} \tau_{i j l}}$

where $M$ represents the total number of trajectories, $l$ represents the index of the trajectory, $C_{l}$ represents the observed concentration when trajectory $l$ arrives in cell $i j$, and $\tau_{i j l}$ represents the time spent by trajectory $l$ in cell $i j$. When $n_{i j}$ was less than three times of the average value of the endpoints per each cell $\left(n_{\text {ave }}\right)$, an arbitrary weight function $\left(W_{i j}\right)$ was multiplied by the PSCF and CWT values (Polissar et al., 2001; Wang et al., 2006) to reduce uncertainty in cells:

$W_{i j}=\left\{\begin{array}{cc}1.00, & 3 n_{\text {ave }}<n_{i j} \\ 0.70, & 2 n_{\text {ave }}<n_{i j} \leq 3 n_{\text {ave }} \\ 0.42, & n_{\text {ave }}<n_{i j} \leq 2 n_{\text {ave }} \\ 0.17, & n_{i j} \leq n_{\text {ave }}\end{array}\right\}$

A detailed description of $W_{i j}$ in this study can be found in the Supplementary Materials. Subsequently, the potential source areas with high weighted PSCF (WPSCF) or weighted CWT (WCWT) values could be determined. 


\section{Results and discussion}

Characteristics of air pollutants and meteorological parameters

Figure 2 shows the time series of air pollutants and meteorological factors in Linfen from December 1, 2019 to February 29, 2020. The mean concentrations of
$\mathrm{PM}_{2.5}, \mathrm{PM}_{10}, \mathrm{NO}_{2}, \mathrm{SO}_{2}, \mathrm{CO}$, and MDA8 $\mathrm{O}_{3}$ during the entire study period were $106.2 \mathrm{\mu g} \mathrm{m}^{-3}, 139.4 \mu \mathrm{g} \mathrm{m}^{-3}$, $47.2 \mu \mathrm{g} \mathrm{m}^{-3}, 41.0 \mu \mathrm{g} \mathrm{m}^{-3}, 1.8 \mathrm{mg} \mathrm{m}^{-3}$, and $57.0 \mu \mathrm{g} \mathrm{m}^{-3}$, respectively. The overall mean $\mathrm{PM}_{2.5} / \mathrm{PM}_{10}$ ratio was 0.73 , which was higher than the ratio observed in winter in Lhasa (0.48) (Yin et al., 2019), Beijing (0.67) (Li et al., 2017a), (Li et al., 2017b), (Rupakheti et al., 2021), demonstrating that $\mathrm{PM}_{2.5}$ accounted for a relatively high proportion
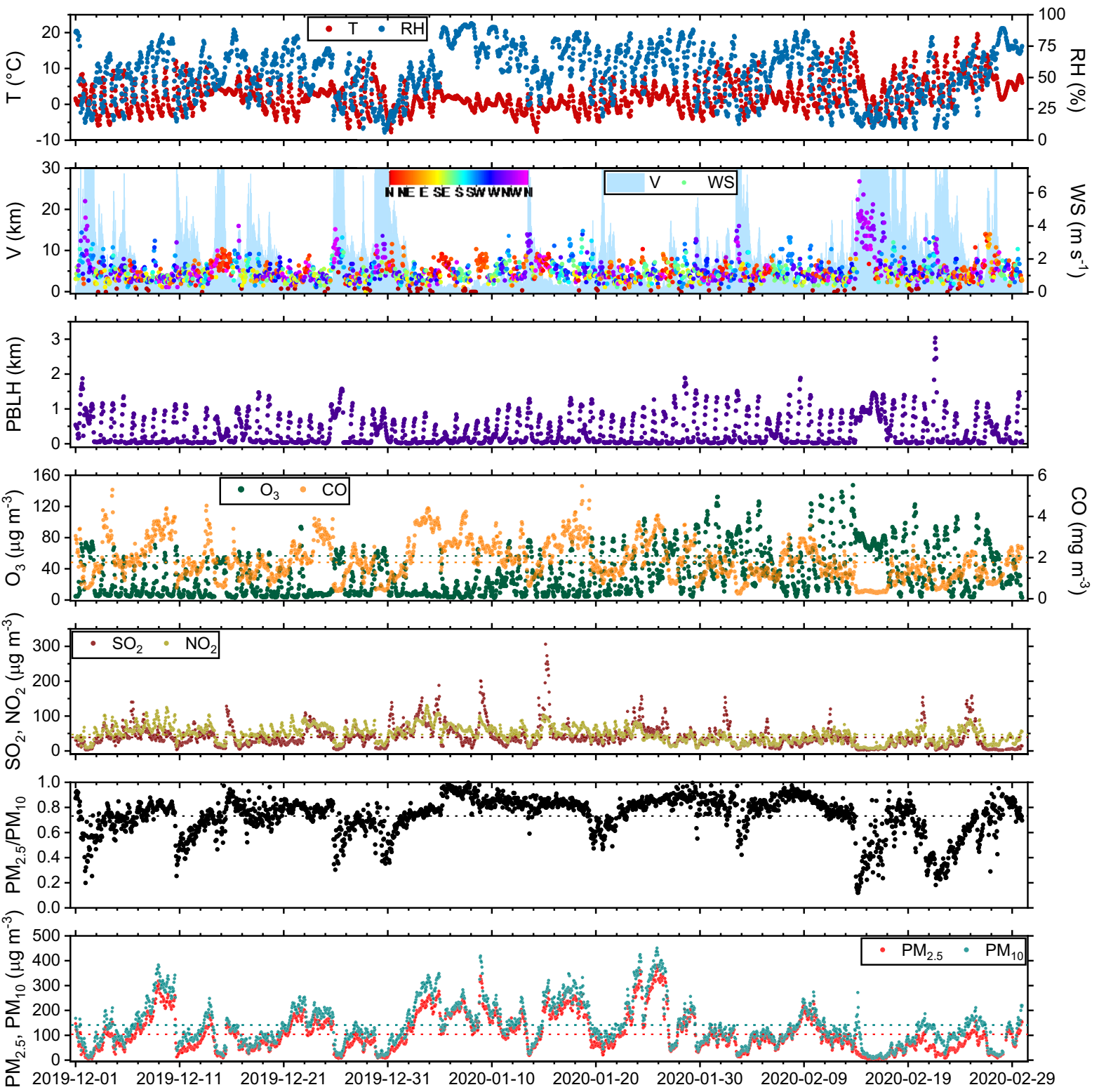

Fig. 2 Temporal variation of meteorological parameters and air pollutants in Linfen from December 1, 2019 to February 29, 2020. The dotted line represents the mean concentration of $\mathrm{PM}_{2.5}, \mathrm{PM}_{10}, \mathrm{NO}_{2}, \mathrm{SO}_{2}, \mathrm{CO}, \mathrm{MDA} 8 \mathrm{O}_{3}$, and mean $\mathrm{PM}_{2.5} / \mathrm{PM}_{10}$ ratio during the entire study period. T temperature, $\mathrm{RH}$ relative humidity, V visibility, WS wind speed, PBLH planetary boundary layer height 
of $\mathrm{PM}_{10}$ and mainly came from primary and secondary anthropogenic sources. $\mathrm{PM}_{2.5}$ was the major pollutant causing air pollution and reduced visibility in Linfen in winter. Qingdao (0.64) (Urumqi (0.70)). The $\mathrm{PM}_{2.5}$ concentration level was higher than the $30.5 \mu \mathrm{g} \mathrm{m}^{-3}$ measured in Lhasa (Yin et al., 2019) and $82.0 \mu \mathrm{g} \mathrm{m}^{-3}$ in Beijing (Zhang et al., 2020) but lower than the $115.7 \mu \mathrm{g} \mathrm{m}^{-3}$ in $\mathrm{Xi}^{\prime}$ an (Yang et al., 2019) and $144.6 \mu \mathrm{g} \mathrm{m}^{-3}$ in Urumqi (Rupakheti et al., 2021) during the winter. Pollution days with the daily concentration of $\mathrm{PM}_{2.5}$ above $75 \mu \mathrm{g} \mathrm{m}^{-3}$ accounted for about $60 \%$ of the total monitored days, and heavily polluted days with the daily concentration of $\mathrm{PM}_{2.5}$ above $150 \mu \mathrm{g} \mathrm{m}^{-3}$ accounted for more than $30 \%$, reflecting severe air pollution in this region.

Six heavy air pollution events occurred on December 8-9 and 22, 2019; January 2-10, 15-18, and 23-26, 2020; and February 8, 2020, with the daily $\mathrm{PM}_{2.5}$ concentration higher than $150 \mu \mathrm{g} \mathrm{m}^{-3}$. Four of the six events had $>2$ consecutive days of high pollution and were thus
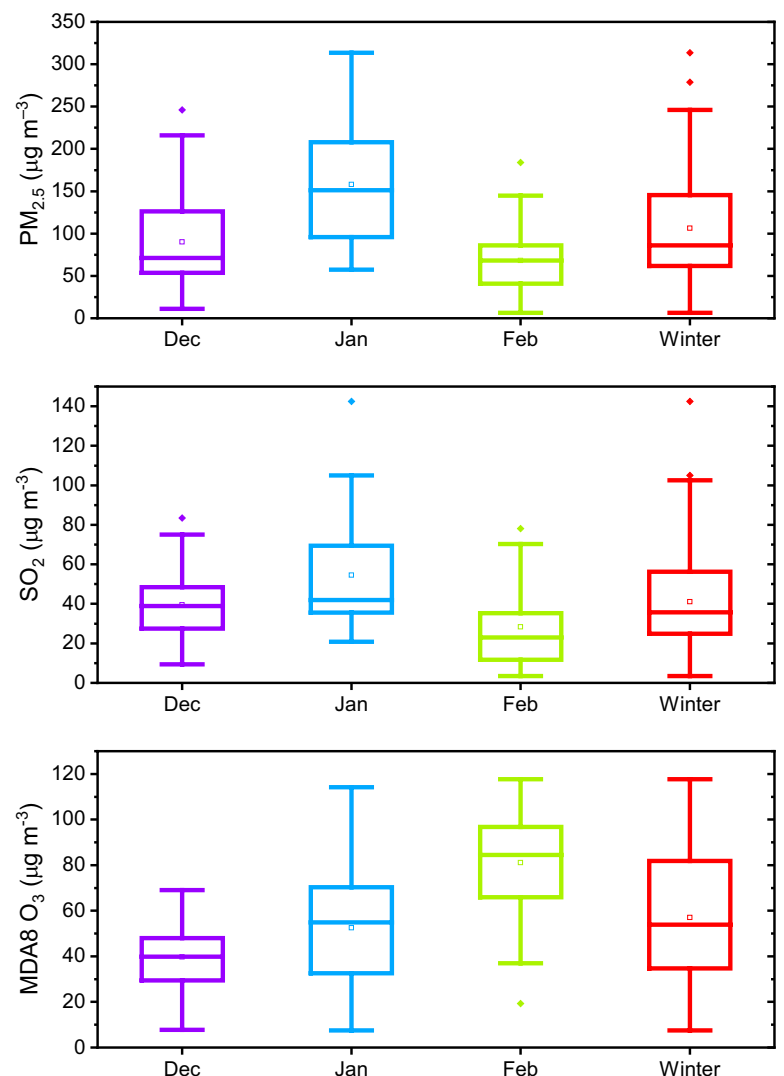

Fig. 3 Monthly variations of $\mathrm{PM}_{2.5}, \mathrm{PM}_{10}, \mathrm{NO}_{2}, \mathrm{SO}_{2}, \mathrm{MDA} 8$ $\mathrm{O}_{3}$, and $\mathrm{CO}$ concentrations in Linfen. The box represents the values from the 25 th to 75 th percentile. The middle line repre- classified as persistent air pollution events; the maximum duration was 9 days. Such pollution events considerably harm the health of residents. Three heavy air pollution events occurred during the Chinese Little New Year (January 17), Spring Festival (January 25), and Lantern Festival (February 8). On these days, the maximum daily mean concentrations of $\mathrm{PM}_{2.5}$ and $\mathrm{PM}_{10}$ reached $314 \mu \mathrm{g} \mathrm{m}^{-3}$ and $370 \mu \mathrm{g} \mathrm{m}^{-3}$, respectively, which were much higher than the NAAQS's daily mean concentration limits of $75 \mu \mathrm{g} \mathrm{m}^{-3}$ and $150 \mu \mathrm{g} \mathrm{m}^{-3}$, respectively. The peak hourly values reached up to $378.0 \mu \mathrm{g} \mathrm{m}^{-3}$ and $449.4 \mathrm{\mu g} \mathrm{m}^{-3}$, respectively. These results indicate that fireworks and firecrackers set off to celebrate traditional Chinese festivals, along with unfavorable air pollutiondiffusion conditions, may cause the concentration of PM pollutants to spike (Ning, 2018).

The statistical results of air pollutants in Linfen in each month are shown in Fig. 3. The daily mean concentrations of $\mathrm{PM}_{2.5}, \mathrm{PM}_{10}, \mathrm{NO}_{2}, \mathrm{SO}_{2}$, and $\mathrm{CO}$ ranged from 6.3
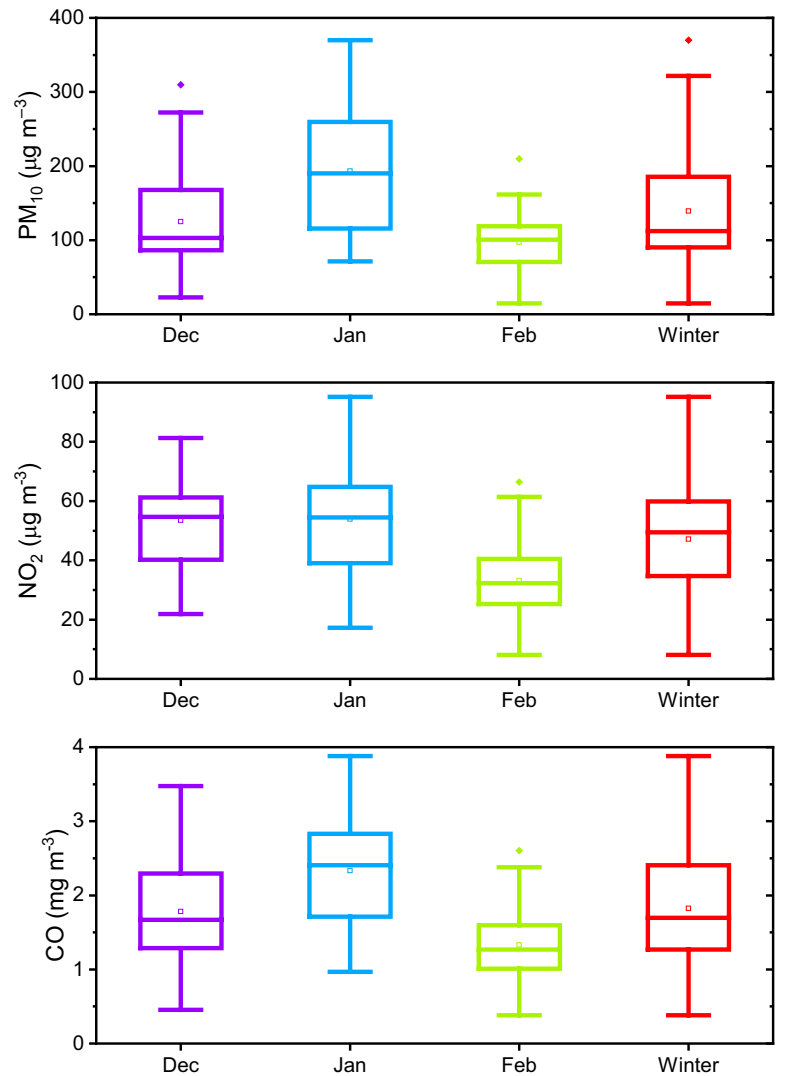

sents the median. The hollow square represents the mean. The vertical line extends to 1.5 times the interquartile range. Outliers are plotted as solid diamonds 
to $313.7 \mu \mathrm{g} \mathrm{m}^{-3}, 14.7$ to $370 \mu \mathrm{g} \mathrm{m}^{-3}, 8.1$ to $95.2 \mu \mathrm{g} \mathrm{m}^{-3}$, 3.5 to $142.5 \mu \mathrm{g} \mathrm{m}^{-3}$, and 0.4 to $3.9 \mathrm{mg} \mathrm{m}^{-3}$, respectively, with the highest concentration in January and the lowest in February. The mean $\mathrm{PM}_{2.5}$ and $\mathrm{PM}_{10}$ concentrations in January were the highest, at $158.1 \mu \mathrm{g} \mathrm{m}^{-3}$ and $193.4 \mu \mathrm{g} \mathrm{m}^{-3}$, respectively, which were similar to that measured in Xinjiang $\left(157.42 \mu \mathrm{g} \mathrm{m}^{-3}\right.$ for $\mathrm{PM}_{2.5}$ and $219.16 \mu \mathrm{g} \mathrm{m}^{-3}$ for $\mathrm{PM}_{10}$ ) (Rupakheti et al., 2021) and exceeded the China NAAQS limit by 2.1 and 1.3 times. The mean $\mathrm{SO}_{2}$ and $\mathrm{CO}$ concentrations were also highest in January, at $54.5 \mu \mathrm{g} \mathrm{m}^{-3}$ and $2.3 \mathrm{mg} \mathrm{m}^{-3}$, respectively. The mean $\mathrm{NO}_{2}$ concentrations were similar in December and January, about $54 \mu \mathrm{g} \mathrm{m}^{-3}$, and then dropped to $28.3 \mu \mathrm{g} \mathrm{m}^{-3}$ in February. By contrast, the MDA8 $\mathrm{O}_{3}$ ranged from 7.5 to $117.8 \mu \mathrm{g} \mathrm{m}^{-3}$, with the maximum found in February and the minimum in January. The mean MDA8 $\mathrm{O}_{3}$ concentration in February was up to $81.2 \mu \mathrm{g} \mathrm{m}^{-3}$.

Figure 4 shows the monthly statistics of meteorological factors in Linfen, including temperature, relative humidity, wind speed, visibility, and PBLH. The daily average temperature was between -3.2 and $10.2{ }^{\circ} \mathrm{C}$, with the minimum in December and the maximum in February. The monthly average temperatures in December, January, and February were $1.9{ }^{\circ} \mathrm{C}, 0.9{ }^{\circ} \mathrm{C}$, and $4.8{ }^{\circ} \mathrm{C}$, respectively. The daily average relative humidity varied from 16.6 to $90.6 \%$. January had the highest monthly average relative humidity of $63.2 \%$, followed by December (49.0\%) and February (47.2\%). The monthly average wind speed and PBLH in February were the highest at $1.5 \mathrm{~m} \mathrm{~s}^{-1}$ and $406.7 \mathrm{~m}$, respectively, and the daily maximum reached $4.1 \mathrm{~m} \mathrm{~s}^{-1}$ and $1168.3 \mathrm{~m}$, respectively, whereas the monthly average wind speed, visibility, and PBLH were the lowest in January at $1.2 \mathrm{~m} \mathrm{~s}^{-1}, 4.7 \mathrm{~km}$, and $270.2 \mathrm{~m}$, respectively. A large number of pollutant emissions and unfavorable meteorological conditions in January contributed to higher pollution levels.

Correlations between air pollutants and meteorological parameters

Spearman's rank coefficients were used to assess the correlation between the levels of all air pollutants. As shown in Table 1, the hourly concentrations of $\mathrm{PM}_{2.5}$
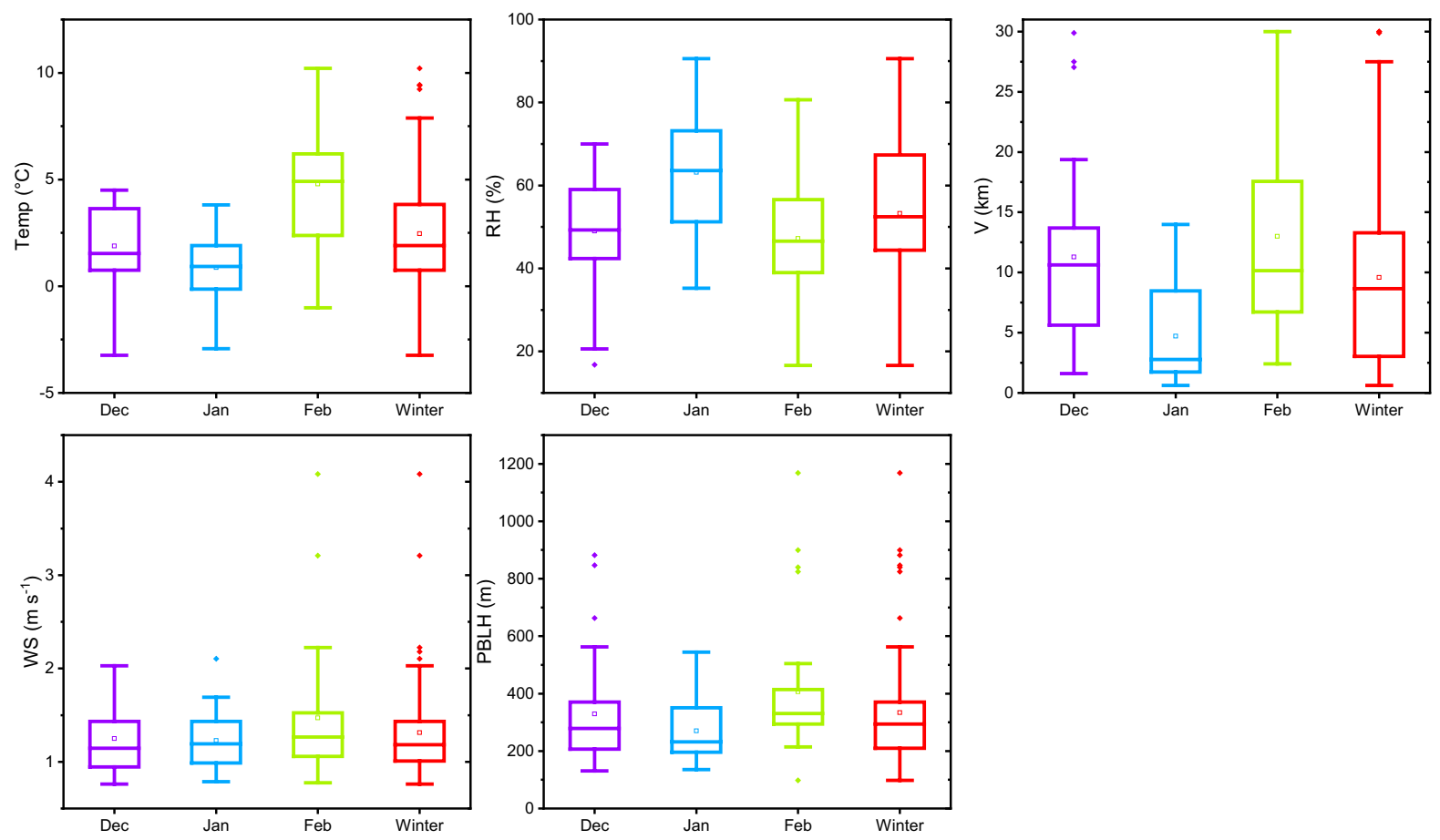

Fig. 4 Monthly statistics of meteorological parameters in Linfen. The box represents the values from the 25 th to 75 th percentile. The middle line represents the median. The hollow square represents the mean. The vertical line extends to 1.5

times the interquartile range. Outliers are plotted as solid diamonds. T temperature, RH relative humidity, WS wind speed, $\mathrm{V}$ visibility, PBLH planetary boundary layer height 
Table 1 Spearman's rank correlations of air pollutants in Linfen based on hourly data for the study period. Correlation coefficients are significant at the 0.01 level

\begin{tabular}{lllllr}
\hline & $\mathrm{PM}_{10}$ & $\mathrm{SO}_{2}$ & $\mathrm{NO}_{2}$ & $\mathrm{O}_{3}$ & $\mathrm{CO}$ \\
\hline $\mathrm{PM}_{2.5}$ & 0.961 & 0.651 & 0.645 & -0.432 & 0.912 \\
$\mathrm{PM}_{10}$ & 1 & 0.651 & 0.679 & -0.436 & 0.888 \\
$\mathrm{SO}_{2}$ & & 1 & 0.712 & -0.461 & 0.644 \\
$\mathrm{NO}_{2}$ & & & 1 & -0.724 & 0.674 \\
$\mathrm{O}_{3}$ & & & & 1 & -0.474 \\
\hline
\end{tabular}

$\mathrm{PM}_{10}, \mathrm{NO}_{2}, \mathrm{SO}_{2}$, and $\mathrm{CO}$ were positively correlated with each other, suggesting that their common origin was the burning of fossil fuels (Wang et al., 2014). Furthermore, $\mathrm{O}_{3}$ had a negative correlation with other pollutants. The most robust relationship was between $\mathrm{NO}_{2}$ and $\mathrm{O}_{3}$, with a correlation coefficient of -0.724 , reflecting the consumption of precursors and formation of oxidation products (Hamoda et al., 2020).

Meteorological conditions have substantial effects on the formation, diffusion, and removal of air pollutants. The Spearman rank correlation coefficient was applied to evaluate the relationships between air pollutants and meteorological factors, including temperature, wind speed, relative humidity, visibility, and PBLH. As shown in Table 2, the concentrations of $\mathrm{PM}_{2.5}, \mathrm{PM}_{10}, \mathrm{NO}_{2}, \mathrm{SO}_{2}$, and $\mathrm{CO}$ were negatively correlated with temperature. The high surface temperature may reduce the stability of temperature stratification, facilitate the vertical motion of the atmosphere, and result in the dilution and dispersion of air pollutants ( $\mathrm{Li}$ et al., 2017d). $\mathrm{O}_{3}$ concentrations were positively correlated with the temperature at a correlation coefficient of 0.577 , which was due to the strong influence of temperature on the production of $\mathrm{O}_{3}$ by accelerating the rate of chemical reactions and increasing the emission of volatile organic compounds from vegetation (Coates et al., 2016). $\mathrm{PM}_{2.5}, \mathrm{PM}_{10}, \mathrm{NO}_{2}, \mathrm{SO}_{2}$, and $\mathrm{CO}$ concentrations were positively correlated with relative humidity, and the correlation coefficients were $0.617,0.549,0.319$, 0.178 , and 0.553 , respectively. High relative humidity increases the concentration of PM by facilitating the partitioning of semivolatile substances into the aerosol phase, and a moister atmosphere normally accompanies the lower boundary layer, thereby further increasing the concentrations of pollutants dominated by those primary sources (Hoshino et al., 2015). Simultaneously, this study found that all air pollutants other than $\mathrm{O}_{3}$ were negatively correlated with wind speed, visibility, and PBLH. Light winds and low PBLH were the cause of weak dilution of primary pollutants and increased formation of secondary PM (Wang et al., 2014), and the accumulation of pollutants further contributed to the decline in visibility. Strong winds enhance the intensity of atmospheric dispersion and dilution, flushing primary and PM pollutants out of the city. Subsequently, enhanced visibility and solar radiation increase the $\mathrm{O}_{3}$ formed by the photochemical reaction ( $\mathrm{Li}$ et al., 2017c), explaining the positive correlation observed between $\mathrm{O}_{3}$ level, wind speed, and visibility.

$T$ temperature, $R H$ relative humidity, $W S$ wind speed, $V$ visibility, $P B L H$ planetary boundary layer height

\section{Diurnal variations of air pollutants}

The diurnal variations of air pollutants for each month were investigated in this study using hourly data to determine potential emission sources. The monthly average diurnal variations of $\mathrm{PM}_{2.5}, \mathrm{PM}_{10}$, $\mathrm{NO}_{2}, \mathrm{SO}_{2}, \mathrm{CO}$, and $\mathrm{O}_{3}$ concentrations in Linfen are shown in Fig. 5. The diurnal variations of $\mathrm{SO}_{2}$ and $\mathrm{CO}$ concentrations had two peaks around 10:00 and 22:00. Coal burning, steelmaking, coking, and electricity production were the main sources of $\mathrm{SO}_{2}$ (Lu et al., 2010). CO is a product of the incomplete combustion of fuel. The main sources of $\mathrm{CO}$ were
Table 2 Spearman's rank correlation coefficients between air pollutants and meteorological parameters in Linfen based on hourly data for the study period. Correlation coefficients are significant at the 0.01 level

\begin{tabular}{lrrrrrr}
\hline & $\mathrm{PM}_{2.5}$ & \multicolumn{1}{c}{$\mathrm{PM}_{10}$} & \multicolumn{1}{c}{$\mathrm{SO}_{2}$} & \multicolumn{1}{c}{$\mathrm{NO}_{2}$} & \multicolumn{1}{c}{$\mathrm{O}_{3}$} & \multicolumn{1}{c}{$\mathrm{CO}$} \\
\hline $\mathrm{T}$ & -0.184 & -0.139 & -0.155 & -0.252 & 0.577 & -0.150 \\
$\mathrm{RH}$ & 0.617 & 0.549 & 0.178 & 0.319 & -0.537 & 0.553 \\
$\mathrm{WS}$ & -0.245 & -0.233 & -0.232 & -0.391 & 0.389 & -0.242 \\
$\mathrm{~V}$ & -0.930 & -0.876 & -0.479 & -0.533 & 0.458 & -0.844 \\
PBLH & -0.297 & -0.291 & -0.319 & -0.491 & 0.518 & -0.232 \\
\hline
\end{tabular}



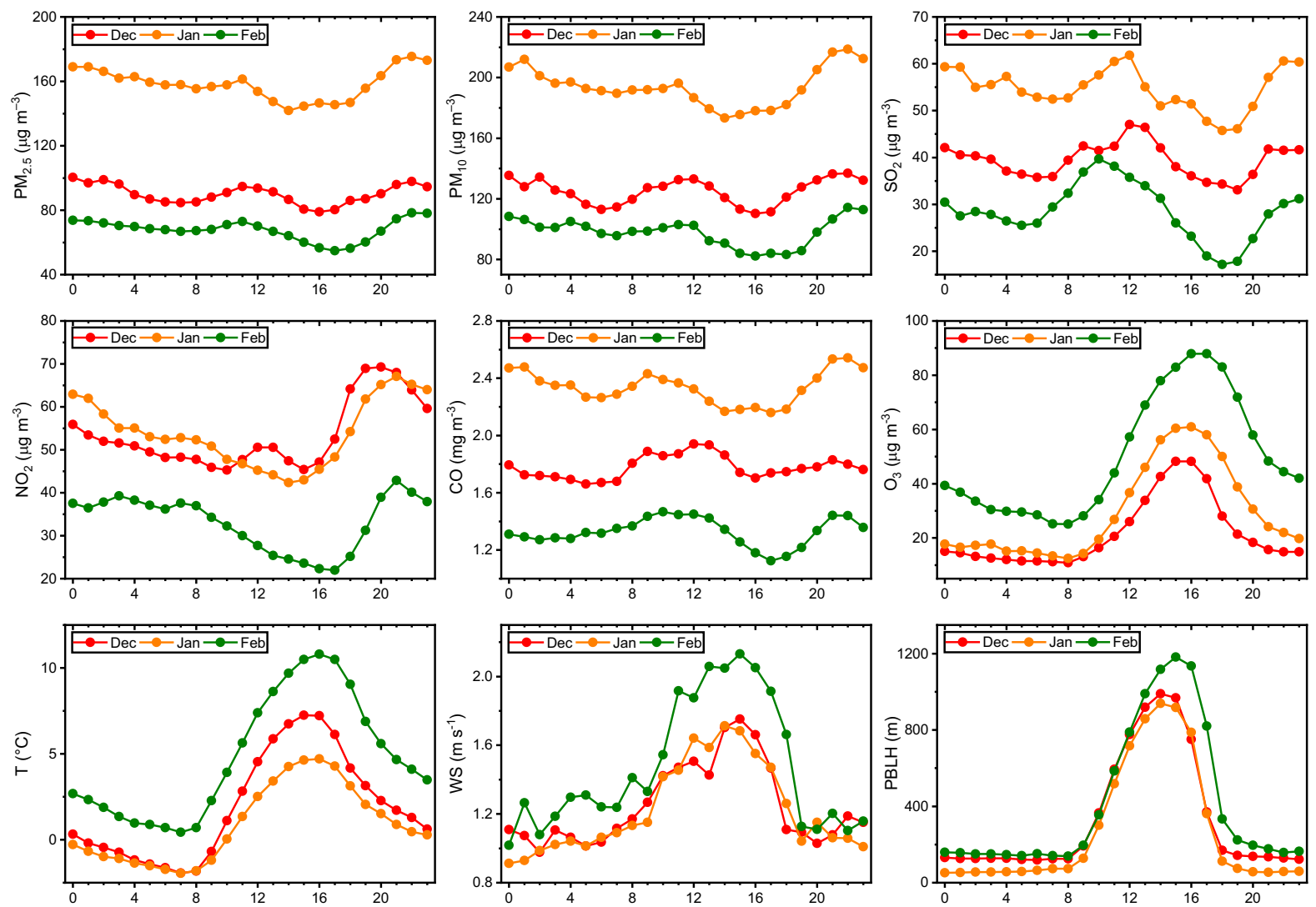

Fig. 5 Diurnal variations of mean concentrations of air pollutants, temperature (T), wind speed (WS), and planetary boundary layer height (PBLH) in Linfen in December 2019, January 2020, and February 2020

steelmaking, coal burning, and vehicle emissions (Streets et al., 2003). The diurnal variations of $\mathrm{NO}_{2}$ concentrations were bimodal, with peaks appearing in the morning rush hour and evening, which indicated that vehicle emissions were the principal source. Steelmaking and electricity production may also contribute to $\mathrm{NO}_{2}$ emissions (Ma \& Jia, 2016).

The diurnal variations of $\mathrm{PM}_{2.5}$ and $\mathrm{PM}_{10}$ had bimodal distributions similar to $\mathrm{NO}_{2}, \mathrm{SO}_{2}$, and $\mathrm{CO}$, indicating that primary emissions such as coal burning, steelmaking, coking, electricity production, and vehicle emissions, as well as the secondary formation of sulfates and nitrates, made essential contributions to PM. Generally, the lower levels of $\mathrm{PM}_{2.5}, \mathrm{PM}_{10}, \mathrm{NO}_{2}, \mathrm{SO}_{2}$, and $\mathrm{CO}$ in the afternoon were caused by higher temperature, wind speed, and PBLH (Fig. 5), which enhanced the dispersion and dilution of air pollutants ( $\mathrm{Li}$ et al., 2017d). In addition, the higher levels before noon and in the evening were mainly attributed to a low PBLH. The diurnal variations of $\mathrm{O}_{3}$ were different from those of other pollutants with a unimodal pattern. The concentration of $\mathrm{O}_{3}$ began to increase rapidly after 8:00 and reached a peak around 16:00. This coincided with the increase in solar radiation and the decrease in $\mathrm{NO}_{2}$, indicating the photochemical reaction and secondary formation of $\mathrm{O}_{3}$.

The concentrations of $\mathrm{PM}_{2.5}, \mathrm{PM}_{10}, \mathrm{SO}_{2}$, and $\mathrm{CO}$ increased sharply in January, followed by December and February. The mean hourly concentrations of $\mathrm{PM}_{2.5}$ and $\mathrm{PM}_{10}$ in January were above $140 \mu \mathrm{g} \mathrm{m}^{-3}$ and $170 \mu \mathrm{g} \mathrm{m}^{-3}$, respectively. The concentrations of $\mathrm{NO}_{2}$ were similar in December and January and higher than that in February. $\mathrm{O}_{3}$ concentration was highest in February, followed by January and December. Business and social activities were suspended to prevent the spread of COVID-19 (Anchordoqui et al., 2020). The decline 
Fig. 6 Air mass back trajectory clusters in Linfen in December (a), January (b), and February (c)

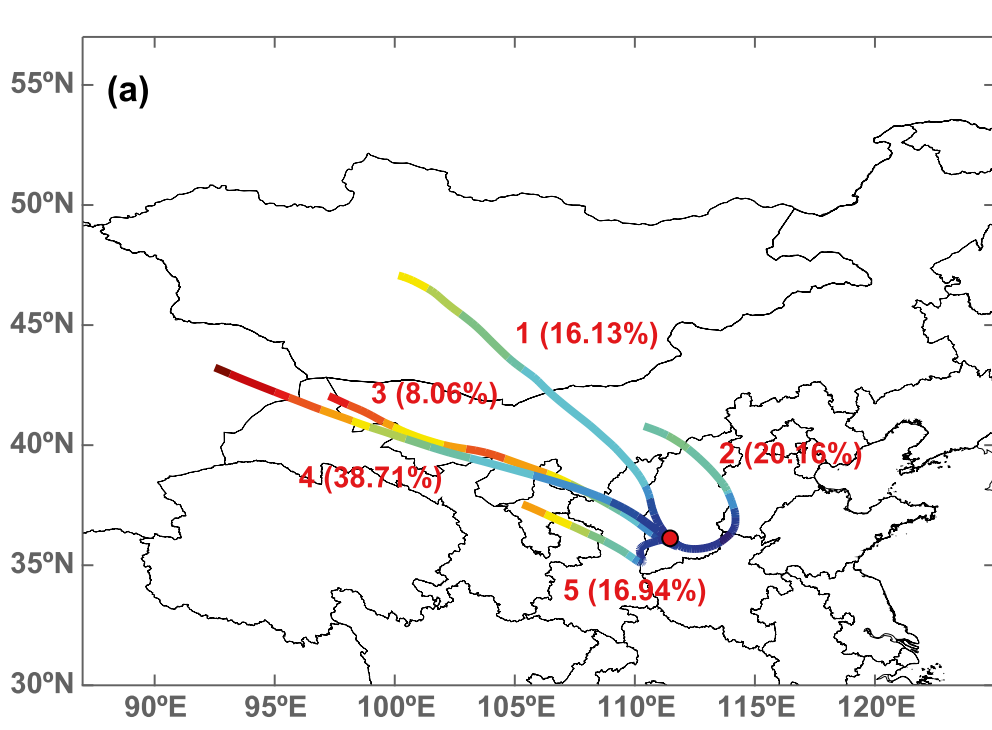

Heigth $(m)$
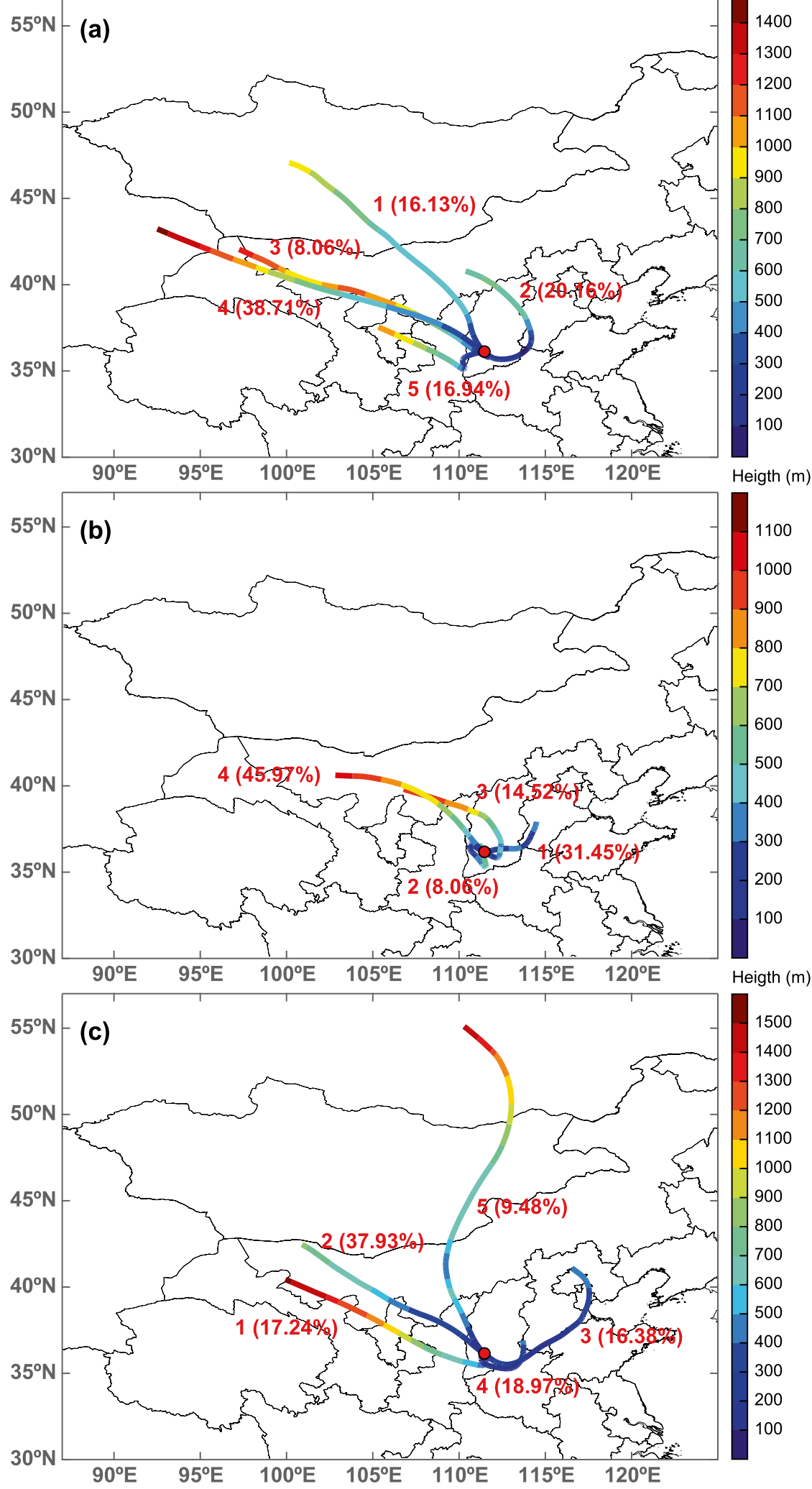
Table 3 Mean $\mathrm{PM}_{2.5}$ concentrations for each cluster

\begin{tabular}{lccc}
\hline Cluster & \multicolumn{3}{l}{$\mathrm{PM}_{2.5}\left(\mu \mathrm{g} \mathrm{m}^{-3}\right)$} \\
\cline { 2 - 4 } & December & January & February \\
\hline 1 & 54.07 & 188.19 & 72.51 \\
2 & 94.76 & 153.98 & 70.69 \\
3 & 83.98 & 155.96 & 59.47 \\
4 & 90.82 & 135.88 & 85.94 \\
5 & 126.98 & - & 19.08 \\
\hline
\end{tabular}

of anthropogenic emissions, mainly from industry and transportation, led to a reduction in air pollutants except for $\mathrm{O}_{3}$ in February.

\section{Pollution pathways and source regions}

Back trajectory clustering has been widely used to illustrate the transport pathway of air masses, and the cluster pathways for each month are shown in Fig. 6. In December, the back trajectories were grouped into five clusters (Fig. 6a). Clusters 1, 2, 3, 4, and 5 accounted for $16.13 \%, 20.16 \%, 8.06 \%, 38.71 \%$, and $16.94 \%$ of the total trajectories, respectively. Cluster 1 was characterized by trajectories from Mongolia, crossing Inner Mongolia and Shaanxi Province, and then reaching Linfen. Cluster 2 was from Inner Mongolia, passing through Shanxi and Hebei provinces before reaching Linfen. Cluster 4 gathered trajectories from Xinjiang and Gansu provinces; subsequently, cluster 4 , together with cluster 3 , passed through Inner Mongolia, Ningxia, and Shaanxi provinces to
Linfen. Mean $\mathrm{PM}_{2.5}$ concentrations related to clusters 2,3 , and 4 were $94.76 \mu \mathrm{g} \mathrm{m}^{-3}, 83.98 \mu \mathrm{g} \mathrm{m}^{-3}$, and $90.82 \mu \mathrm{g} \mathrm{m}^{-3}$, respectively. Cluster 5 originated from Ningxia Province, passed through Gansu and Shaanxi provinces to Linfen. The mean $\mathrm{PM}_{2.5}$ concentration related to cluster 5 was the highest among all clusters at $126.98 \mu \mathrm{g} \mathrm{m}^{-3}$.

In January, the back trajectories were divided into four clusters (Fig. 6b). Clusters 1, 2, 3, and 4 accounted for $31.45 \%, 8.06 \%, 14.52 \%$, and $45.97 \%$ of all the trajectories, respectively. Cluster 1 had the highest mean $\mathrm{PM}_{2.5}$ concentration of $188.19 \mu \mathrm{g} \mathrm{m}^{-3}$, which was derived from Hebei Province to Linfen. Cluster 2 began from the south of Shanxi Province with a short transport pattern. Clusters 3 and 4 were from Inner Mongolia, passing through Shaanxi Province before arriving at Linfen. Mean $\mathrm{PM}_{2.5}$ loadings related to clusters 2,3 , and 4 were $153.98 \mu \mathrm{g} \mathrm{m}^{-3}$, $155.96 \mu \mathrm{g} \mathrm{m}^{-3}$, and $135.88 \mu \mathrm{g} \mathrm{m}^{-3}$, respectively.

In February, the back trajectories were grouped into five clusters (Fig. 6c). Clusters 1, 2, 3, 4, and 5 accounted for $17.24 \%, 37.93,16.38 \%, 18.97 \%$, and $9.48 \%$ of all the trajectories, respectively. Clusters 1 and 2 came from Inner Mongolia, passed through Ningxia and Shaanxi Provinces, and then reached Linfen. Cluster 3 began in Beijing; traveled through Tianjin, Hebei, Shandong, and Henan provinces; and finally reached Linfen. Cluster 4 was from Hebei and Henan provinces to Linfen, and the mean $\mathrm{PM}_{2.5}$ concentration was the highest, at $85.94 \mu \mathrm{g} \mathrm{m}^{-3}$. Cluster 5 represented long-range transport and fast-moving trajectories. It originated in Russia and reached Linfen
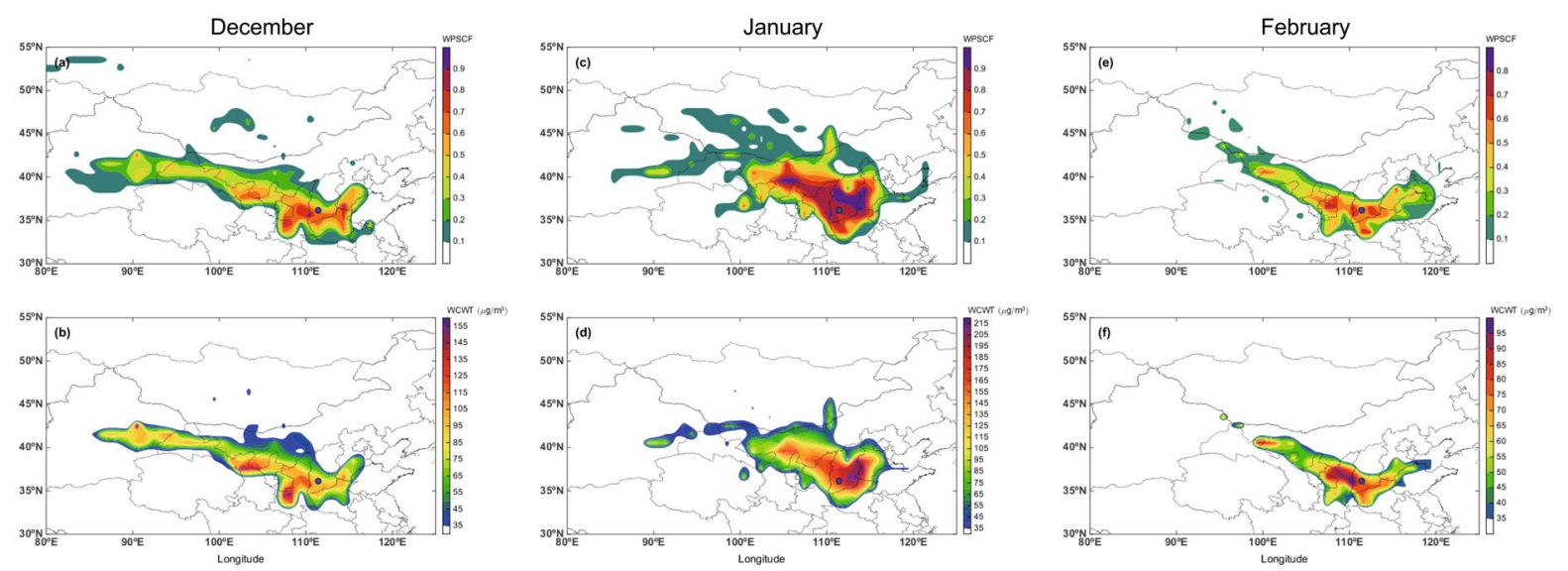

Fig. 7 Weighted potential source contribution function (WPSCF) and weighted concentration weighted trajectory (WCWT) maps of $\mathrm{PM}_{2.5}$ in December (a, b), January $(\mathbf{c}, \mathbf{d})$, and February $(\mathbf{e}, \mathbf{f})$ 
after passing through Mongolia, Inner Mongolia, and Shaanxi Province (Table 3).

The WPSCF and WCWT maps describe the potential source areas of $\mathrm{PM}_{2.5}$. In December (Fig. 7a, b), the main pollution source areas include Xinjiang Province, the middle and east of Gansu Province, the south of Inner Mongolia, the middle of Shaanxi Province, the south of Shanxi Province, the south of Hebei Province, and the north of Henan Province. The WPSCF and WCWT values of these areas were higher than 0.6 and $95 \mu \mathrm{g} \mathrm{m}^{-3}$, respectively. In January (Fig. 7c, d), the critical pollution source regions with WPSCF values exceeding 0.8 and WCWT values exceeding $130 \mu \mathrm{g} \mathrm{m}^{-3}$ included the south of Inner Mongolia, the north of Shaanxi Province, the south of Shanxi Province, and the southwest of Hebei Province. In February (Fig. 7e, f), the north of Gansu Province, the middle of Shaanxi Province, the south of Shanxi Province, and the northeast of Henan Province were the central source regions. The WPSCF values were higher than 0.5 , and the WCWT values were higher than $75 \mu \mathrm{g} \mathrm{m}^{-3}$.

\section{Conclusion}

This study investigated the variations of $\mathrm{PM}_{2.5}, \mathrm{PM}_{10}$, $\mathrm{NO}_{2}, \mathrm{SO}_{2}, \mathrm{CO}$, and $\mathrm{O}_{3}$ in Linfen from December 1 , 2019 to February 29. 2020. $\mathrm{PM}_{2.5}$ was the major pollutant causing air pollution during the study period. Six heavy air pollution events occurred with the daily $\mathrm{PM}_{2.5}$ concentration exceeded $150 \mu \mathrm{g} \mathrm{m}^{-3}$, which reflects the severe air pollution in Linfen during winter and the potential threat to the health of residents. The maximum daily mean $\mathrm{PM}_{2.5}$ concentrations reached $314 \mu \mathrm{g} \mathrm{m}^{-3}$, and the peak hourly values were up to $378.0 \mu \mathrm{g} \mathrm{m}^{-3}$. Fireworks and firecrackers set off to celebrate traditional Chinese festivals may cause the concentration of PM pollutants to spike. The Spearman rank correlation coefficient was used to assess the relationships between air pollutants and meteorological factors. Except for $\mathrm{O}_{3}$, the concentrations of $\mathrm{PM}_{2.5}, \mathrm{PM}_{10}$, $\mathrm{NO}_{2}, \mathrm{SO}_{2}$, and $\mathrm{CO}$ were negatively correlated with temperature, wind speed, visibility, and PBLH but positively correlated with relative humidity. Large concentrations of pollutant emissions and unfavorable weather conditions, such as lower temperature, weaker wind, higher relative humidity, and reduced PBLH, led to higher pollution levels. Suspensions of social and business activities due to COVID-19 helped reduce anthropogenic emissions, mainly from industry and transportation, and reduced air pollutants other than $\mathrm{O}_{3}$. Air mass back trajectory clusters, PSCF, and CWT analyses demonstrated that $\mathrm{PM}_{2.5}$ pollution mainly comes from local emissions in Shanxi Province and regional transport from Inner Mongolia, Shaanxi, Hebei, Henan, and Gansu provinces.

The industrial structure of Linfen is heavy-with coal, coke, steel, and electricity being the leading industries-causing vast quantities of industrial emissions. Such heavy industry must urgently transition to ultra-low emission processes to significantly reduce the air pollutants in the flue gas and improve its environmental management standards (Cui, 2020). The energy structure is dominated by coal, and improvements to the level of clean utilization and structural adjustments toward clean alternative energy are necessary. Coal and coke are mainly transported by road, and the problem of vehicle emissions is prominent. Measures should be taken to eliminate the use of heavy diesel vehicles, develop clean-energy vehicles, strengthen the control of large-scale transportation, and increase the proportion of railway transportation to reduce traffic emissions (Abdulkareem et al., 2020; Angelevska et al., 2021). Moreover, more effective emission reduction measures should be adopted in Shanxi and surrounding provinces to reduce regional emissions. These findings will help policy-makers draft plans and policies to reduce air pollution in Linfe.

Author contribution Conceptualization: Lei Liu. Formal analysis and investigation: Lei Liu. Writing-original draft preparation: Lei Liu. Writing-review and editing: Xin Ma, Wei Wen, Chang Sun, Jiao Jiao. Funding acquisition: Lei Liu, Wei Wen.

Funding This work was supported by the National Natural Science Foundation of China (21806183 and 51808549).

Data availability The data analyzed in this study were obtained from the Urban Air Quality Real-time Publishing Platform of China (http://106.37.208.233:20035/) and the Chinese National Meteorological Science Data Center (http://data. cma.cn). 


\section{Declarations}

Conflicts of interest The authors declare that they have no competing 386 interests.

\section{References}

Abdulkareem, M. N., Alsaidi, L. R., Yazid, M. R. M., Borhan, M. N., \& Mahdi, M. S. (2020). Traffic congestion: shift from private car to public transportation Civil. Engineering Journal, 6, 1547-1554.

Action plan for comprehensive treatment of air pollution in the Fenwei Plain in the autumn and winter of 2019-2020. (2019). http://www.mee.gov.cn/xxgk2018/xxgk/xxgk03/ 201911/t20191112_741904.html

Air pollution prevention and control action plan. (2013). http:// www.gov.cn/zwgk/2013-09/12/content_2486773.html

Air quality report in Chinese cities in January 2019. (2019). http://www.cnemc.cn/jcbg/kqzlzkbg/201903/t20190328_ 697744.html

Air quality report of 74 cities in China in January 2013. (2013). http://www.cnemc.cn/jcbg/kqzlzkbg/201302/ t20130207_646922.html

Anchordoqui, JBD., et al. (2020). A physics modeling study of COVID-19 transport in air. SciMedicine Journal, 2, 83-91. https://doi.org/10.28991/SciMedJ202002SI7

An, Z. S., et al. (2019). Severe haze in northern China: a synergy of anthropogenic emissions and atmospheric processes. Proceedings of the National Academy of Sciences of the United States of America, 116, 8657-8666. https:// doi.org/10.1073/pnas.1900125116

Angelevska, B., Atanasova, V., \& Andreevski, I. (2021). Urban air quality guidance based on measures categorization in road transport Civil. Engineering Journal, 7, 253267. https://doi.org/10.28991/cej-2021-03091651

Announcement on the final assessment results of the implementation of the Air Pollution Prevention and Control Action Plan. (2018). http://www.mee.gov.cn/gkml/ sthjbgw/stbgth/201806/t20180601_442262.html

A review of the economic and social development achievement of Linfen. (2019). http://linfen.gov.cn/contents/ 310/474257.html

Coates, J., Mar, K. A., Ojha, N., \& Butler, T. M. (2016). The influence of temperature on ozone production under varying NOx conditions - a modelling study. Atmospheric Chemistry and Physics, 16, 11601-11615. https://doi. org/10.5194/acp-16-11601-2016

Cui, L., et al. (2020). Life cycle assessment of ultra-low treatment for steel industry sintering flue gas emissions. Science of The Total Environment, 725, 138292. https:// doi.org/10.1016/j.scitotenv.2020.138292

Hamoda, M. F., Al-Jaralla, R., \& Al-Mahamel, S. (2020). Assessment of air pollutants emissions due to traffic in two residential areas in Kuwait. International Journal of Environmental Science and Technology. https://doi.org/ 10.1007/s13762-020-02941-4

Hoshino, T., Hoshino, A., \& Nishino, J. (2015). Relationship between environment factors and the number of outpatient visits at a clinic for nonallergic rhinitis in Japan, extracted from electronic medical records. European journal of medical research, 20(1), 1-17. https://doi.org/10.1186/ s40001-015-0151-3

Li, D. P., et al. (2017a). Identification of long-range transport pathways and potential sources of PM2.5 and PM10 in Beijing from 2014 to 2015. Journal Of Environmental Sciences, 56, 214-229. https://doi.org/10.1016/j.jes.2016.06.035

Li, L. Y., Yan D. Y., Xu S. H., Huang, M. L., Wang, X. X., Xie, S. D. (2017b). Characteristics and source distribution of air pollution in winter in Qingdao, eastern China. Environmental Pollution, 224, 44-53. https://doi.org/10. 1016/j.envpol.2016.12.037

Li, R., et al. (2017c). Spatial and temporal variation of particulate matter and gaseous pollutants in China during 20142016. Atmospheric Environment, 161,235-246. https:// doi.org/10.1016/j.atmosenv.2017.05.008

Li, X., Ma, Y., Wang, Y., Liu, N., \& Hong, Y. (2017d ). Temporal and spatial analyses of particulate matter (PM10 and PM2. 5) and its relationship with meteorological parameters over an urban city in northeast China. Atmospheric research, 198, 185-193. https://doi.org/10.1016/j.atmosres. 2017.08.023

Liu, L., Liu, Y., Wen, W., Liang, L., Ma, X., Jiao, J., \& Guo, K. (2020). Source identification of trace elements in PM2. 5 at a rural site in the North China Plain. Atmosphere, 11(2), 179. https://doi.org/10.3390/atmos11020179

Lu, Z., et al. (2010). Sulfur dioxide emissions in China and sulfur trends in East Asia since. Atmospheric Chemistry and Physics, 10, 6311-6331. https://doi.org/10.5194/ acp-10-6311-2010

Ma, M., Hu, S., Cao, L., Appel, E., \& Wang, L. (2015). Atmospheric pollution history at Linfen (China) uncovered by magnetic and chemical parameters of sediments from a water reservoir. Environmental pollution, 204, 161172. https://doi.org/10.1016/j.envpol.2015.04.028

Ma, X., \& Jia, H. (2016). Particulate matter and gaseous pollutions in three megacities over China: situation and implication. Atmospheric Environment, 140, 476-494. https:// doi.org/10.1016/j.atmosenv.2016.06.008

Mulenga, D., \& Siziya, S. (2019). Indoor air pollution related respiratory ill health, a sequel of biomass use. SciMedicine Journal, 1(1), 30-37. https://doi.org/10.28991/SciMedJ2019-0101-5

Ning, G., et al. (2018). Impact of low-pressure systems on winter heavy air pollution in the northwest Sichuan Basin. China Atmos Chem Phys, 18, 13601-13615. https://doi. org/10.5194/acp-18-13601-2018

Polissar, A. V., Hopke, P. K., \& Harris, J. M. (2001). Source regions for atmospheric aerosol measured at Barrow. Alaska Environmental Science \& Technology, 35, 42144226. https://doi.org/10.1021/es0107529

Rupakheti, D., Yin, X., Rupakheti, M., Zhang, Q., Li, P., Rai, M., \& Kang, S. (2021). Spatio-temporal characteristics of air pollutants over Xinjiang, northwestern China. Environmental Pollution, 268, 115907. https://doi.org/10.1016/j. envpol.2020.115907

Shang, Y., et al. (2013). Systematic review of Chinese studies of short-term exposure to air pollution and daily mortality. Environment International, 54, 100-111. https://doi.org/ 10.1016/j.envint.2013.01.010 
Shrivastava, M., et al. (2017). Recent advances in understanding secondary organic aerosol: Implications for global climate forcing. Reviews of Geophysics, 55, 509-559. https:// doi.org/10.1002/2016rg000540

Streets, D. G., et al. (2003). An inventory of gaseous and primary aerosol emissions in Asia in the year 2000. Journal of Geophysical Research: Atmospheres, 108(D21). https:// doi.org/10.1029/2002JD003093

Three-year action plan for defending the blue sky. (2018). http://www.gov.cn/zhengce/content/2018-07/03/ content_5303158.html

Wang, Y., et al. (2014). Spatial and temporal variations of six criteria air pollutants in 31 provincial capital cities in China during 2013-2014. Environmental International, 73, 413-422. https://doi.org/10.1016/j.envint.2014.08.016

Wang, Y. Q., et al. (2006). The contribution from distant dust sources to the atmospheric particulate matter loadings at $\mathrm{XiAn}$. China during spring Science Of the Total Environment, 368, 875-883. https://doi.org/10.1016/j.scitotenv. 2006.03.040

Wang, Y. Q., et al. (2009). TrajStat: GIS-based software that uses various trajectory statistical analysis methods to identify potential sources from long-term air pollution measurement data. Environmental Modelling \& Software, 24, 938-939. https://doi.org/10.1016/j.envsoft.2009.01.004

Wen, W., He, X., Ma, X., Wei, P., Cheng, S., Wang, X., \& Liu, L. (2018). Understanding the regional transport contributions of primary and secondary PM2. 5 components over Beijing during a severe pollution episodes. Aerosol and Air Quality Research, 18(7), 1720-1733. https://doi.org/ 10.4209/aaqr.2017.10.0406
Wen, W., Ma, X., Guo, C., Wei, P., Zhao, X., \& Xu, J. (2020). Source apportionment of black carbon and the feedback effect on the meteorological factors in Beijing. China Environmental Science and Pollution Research. https:// doi.org/10.1007/s11356-020-09881-Z

Xie, Y., Dai, H. C., Zhang, Y. X., Wu, Y. Z., Hanaoka, T., Masui, T. (2019). Comparison of health and economic impacts of PM2.5 and ozone pollution in China. Environmental International, 130, 12. https://doi.org/10.1016/j. envint.2019.05.075

Yang, X., et al. (2019). New method for evaluating winter air quality: PM2.5 assessment using Community Multi-Scale Air Quality Modeling (CMAQ) in Xi'an. Atmospheric Environment, 211, 18-28. https://doi.org/10.1016/j. atmosenv.2019.04.019

Yin, X., de Foy, B., Wu, K., Feng, C., Kang, S., \& Zhang, Q. (2019). Gaseous and particulate pollutants in Lhasa, Tibet during 2013-2017: Spatial variability, temporal variations and implications. Environmental Pollution, 253, 68-77.

Zhang, L., et al. (2020). Spatiotemporal variations and influencing factors of PM2.5 concentrations in Beijing, China. Environmental Pollution, 262, 114276. https://doi. org/10.1016/j.envpol.2020.114276

Publisher's Note Springer Nature remains neutral with regard to jurisdictional claims in published maps and institutional affiliations. 